\title{
Histopathological and ultrastructural characteristics of myeloid leukosis in broiler chicken
}

[Características histopatológicas e ultraestruturais da leucose mielóide em galinhas de linhagem pesada]

\author{
R.M. Manzan ${ }^{1}$, M.R. Baccaro $^{2}$, A.J.P. Ferreira ${ }^{2}$, I.L. Sinhorini ${ }^{2}$, A.M. Moreno ${ }^{2} *$ \\ ${ }^{1}$ Aluno de pós-graduação - FMVZ - UNESP- Botucatu, SP \\ ${ }^{2}$ Faculdade de Medicina Veterinária e Zootecnia - USP \\ Av. Prof. Dr. Orlando Marques de Paiva, 87 \\ 05508-000 - São Paulo, SP
}

\begin{abstract}
An ultrastructural and histological study was performed to determine the degree of differentiation of the neoplastic cells. The histological study revealed neoplastic cells with pleomorphism, oval nuclei, prominent nucleoli, irregularly distributed chromatin, atypical mitotic figures and moderate amount of cytoplasm containing spherical eosinophilic granulations, typical features of the myeloid lineage. Ultrastructurally, there were cells with an electron-dense, oval and voluminous nucleus, with predominant euchromatin and cytoplasm containing many spherical, electron-dense and homogeneous granules, indicative of myelocytes with differentiation to eosinophils. Type-C viral particles were also seen in the intercellular space of renal tubules and inside the intracytoplasmic vesicles of immature myelocytes in the bone marrow and ovary. PCR was positive to ALV-J.
\end{abstract}

Keywords: chicken, avian leukosis, avian oncovirus, histopathology, ultrastructure

\section{RESUMO}

Caracterizaram-se a linhagem e o grau de diferenciação das células neoplásicas no estudo histopatológico e ultraestrutural da leucose mielóide. Histologicamente as células neoplásicas apresentaram pleomorfismo, núcleos ovais, nucléolos proeminentes, cromatina distribuída de maneira irregular, figuras de mitose atípicas e moderada quantidade de citoplasma contendo granulações eosinofilicas esféricas. Essas características indicam a linhagem mielóide. Ultraestruturalmente evidenciaram-se células com núcleo oval, volumoso, eletrodenso, com predomínio de eucromatina e citoplasma com numerosos grânulos esféricos, eletrodensos e homogêneos, indicando mielócitos com diferenciação para eosinófilos. Constatou-se também a presença de partículas virais tipo-C no espaço intercelular dos túbulos renais, no interior de vesículas intracitoplasmáticas dos mielócitos imaturos presentes na medula óssea e ovário, e PCR positivo para ALV-J.

Palavras-chave: galinha, leucose aviária, oncovírus aviário, histopatologia, ultra-estrutura

\section{INTRODUCTION}

Myeloid leukosis is a neoplastic disease caused by the avian leukosis virus, subgroup J (ALV-J). The disease is one of the main causes of mortality in chickens. Since ALV-J was firstly reported in the United Kingdom, in 1989 (Payne et al., 1991), there are important studies on the molecular aspects of this virus (Venugopal, 1999; Silva et al., 2000), the pathogenesis of this disease (Stedman et al., 2001), diagnostic methods (Fadly, 2000; Qin et al., 2001) and mode of transmission of viruses (Witter and Fadly, 2001).

Recebido em 2 de setembro de 2004

Aceito em 13 de dezembro de 2005

*Corresponding author (autor para correspondência)

E-mail: morenoam@usp.br

Apoio: FAPESP (Proc. 98/15560-0) 
ALV-J has a tropism for chicken bone marrow cells and induces their neoplastic transformation (Payne, 1992). Myeloid neoplasia arises from primordial haematopoietic cells that originate myeloid lineage cells (erythrocytes, granulated leukocytes, monocytes and thrombocytes). The common aspect in the heterogeneous group of myeloid tumors is the origin from a progenitor cell that normally produces terminal differentiation cells of the myeloid series (Aster and Kumar, 1999).

Histologically, myeloid leukosis consists of pure populations of myelocytes in several differentiation stages (Payne et al., 1992). There is an exuberant proliferation of immature myelocytes with voluminous nuclei, evident nucleolus and cytoplasm filled with eosinophilic granules and numerous mitoses (Payne and Fadly, 1997).

Some authors state that in myeloid leukosis the neoplastic cells are originated from the myelomonocytic lineage at the final stage of differentiation, myelocytes or monocytes (Payne, 1998), while others postulate that the origin may be in the myeloblasts (Jordan and Pattison, 1996). An experimental inoculation of the virus in a bone marrow cell culture showed that the transformed cells had morphologic features suggestive of macrophage precursor cells (Payne et al., 1993).

According to the literature, it is agreed that myeloid leukosis is a proliferation of myelocytes, but nothing is argued about the differentiation. In birds, myelocytes can originate three types of granular leukocytes: heterophils, eosinophils, and basophils (Hodges, 1974).

Microscopically, it is very difficult to distinguish the heterophil from the eosinophil, once both have eosinophilic intracytoplasmic granules (Campbell, 1988). The differentiation is possible by the use of cytochemic markers (Andreasen and Latimer, 1990). Using the electron microscope it is possible to differentiate heterophil and eosinophil myelocytes, according to the structure of their granules (Dhringa et al., 1969; Maxwell and Trejo, 1970; Hodges, 1974).

There are few electron microscopy studies describing ultrastructural characteristics of myeloid leukosis (Nakamura et al., 2000). The purpose of this investigation was to study the myeloid leukosis both histologically and ultrastructurally, attempting to determine the lineage of differentiation of the neoplastic cells of this tumor.

\section{MATERIALS AND METHODS}

Nineteen adult chickens were purchased from a commercial broiler breeder flock with a history of myeloid leukosis and with positive classification for ALV-J, based on testing programmes performed by the company. All birds were euthanized and necropsied. In 16 chicken, gross tumors were observed at necropsy and samples of liver, spleen, ovary, sternum and kidney were collected and fixed in $10 \%$ buffered formalin. The sternum was decalcified in $37 \%$ formic acid and $6.8 \%$ sodium format. Then, tissue samples were embedded in paraffin, sectioned at $4 \mu \mathrm{m}$ and stained with haematoxylin and eosin for light microscopic examination.

The neoplastic tissues were fixed with $2 \%$ glutaraldehyde and postfixed in $1 \%$ osmium tetroxide, dehydrated in graded acetone and embedded into Araldite 502 resin. Thick sections of $1 \mu \mathrm{m}$ were stained with Giemsa to obtain select areas. Then, ultrathin sections (40 to $50 \mathrm{~nm})$ were stained with saturated alcoholic uranyl acetate and lead citrate, allowing their examination by the transmission electron microscope ${ }^{1}$.

Polymerase chain reaction (PCR) was used to test DNA from tumorous tissues (liver and bone marrow) of affected chickens, employing ALV-J specific primers. The sequences of the oligonucleotide primers ( $\mathrm{H} 5$ and $\mathrm{H} 7$ ) used in the study were selected from the published sequences (Smith et al., 1998). Primers were obtained from Life Technologies ${ }^{2}$.

\section{RESULTS}

The histological examination of the neoplastic fragments of the bone marrow, liver, spleen, ovary and kidneys showed a marked proliferation of immature myeloid cells (Fig. 1A).

\footnotetext{
${ }^{1}$ Phillips EM-201

${ }^{2}$ Life Technologies - Grand Island, NY - USA
} 
Hypercellularity, high nuclear/cytoplasmic ratio, large and prominent nucleoli, coarse nuclear chromatin and abnormal mitoses were observed.

Neoplastic cells were of different sizes (cellular pleomorphism) and had oval, voluminous, eccentrally located nuclei with thickened and irregular contours. Nuclei usually had prominent nucleoli and a chromatin pattern that varied from finely stippled into larger to condensed clumps, as well as atypical mitosis. The cytoplasm contained few to many spherical eosinophilic granules (Fig. 1B).

Ultrastructurally, the cells frequently had oval, voluminous, electron-dense nuclei, with predominance of euchromatin, slightly irregular contour due to small indentations and evident nucleolus. Many spherical, electron-dense and homogeneous granules were observed in the cytoplasm. All granules had a similar size and electron density (Fig. 1C).

The cytoplasm was moderate in amount and contained abundant polyribosomes, with a considerable number of ribosomes, moderate numbers of mitochondria, and a few profiles of rough endoplasmic reticulum.

Electron microscopic examination revealed viral particles in the intercellular space of the renal tubules and inside the intracytoplasmic vesicles of immature myelocytes in the bone marrow and ovary. Those particles were 100 to $120 \mathrm{~nm}$ in diameter, spherical in shape with an inner, centrally located electron-dense core surrounded by a double layer envelope, separated from it by an electron lucent space (Fig. 1D).

DNA from tissue samples tested positive in the PCR, resulting in a product of $545 \mathrm{bp}$.

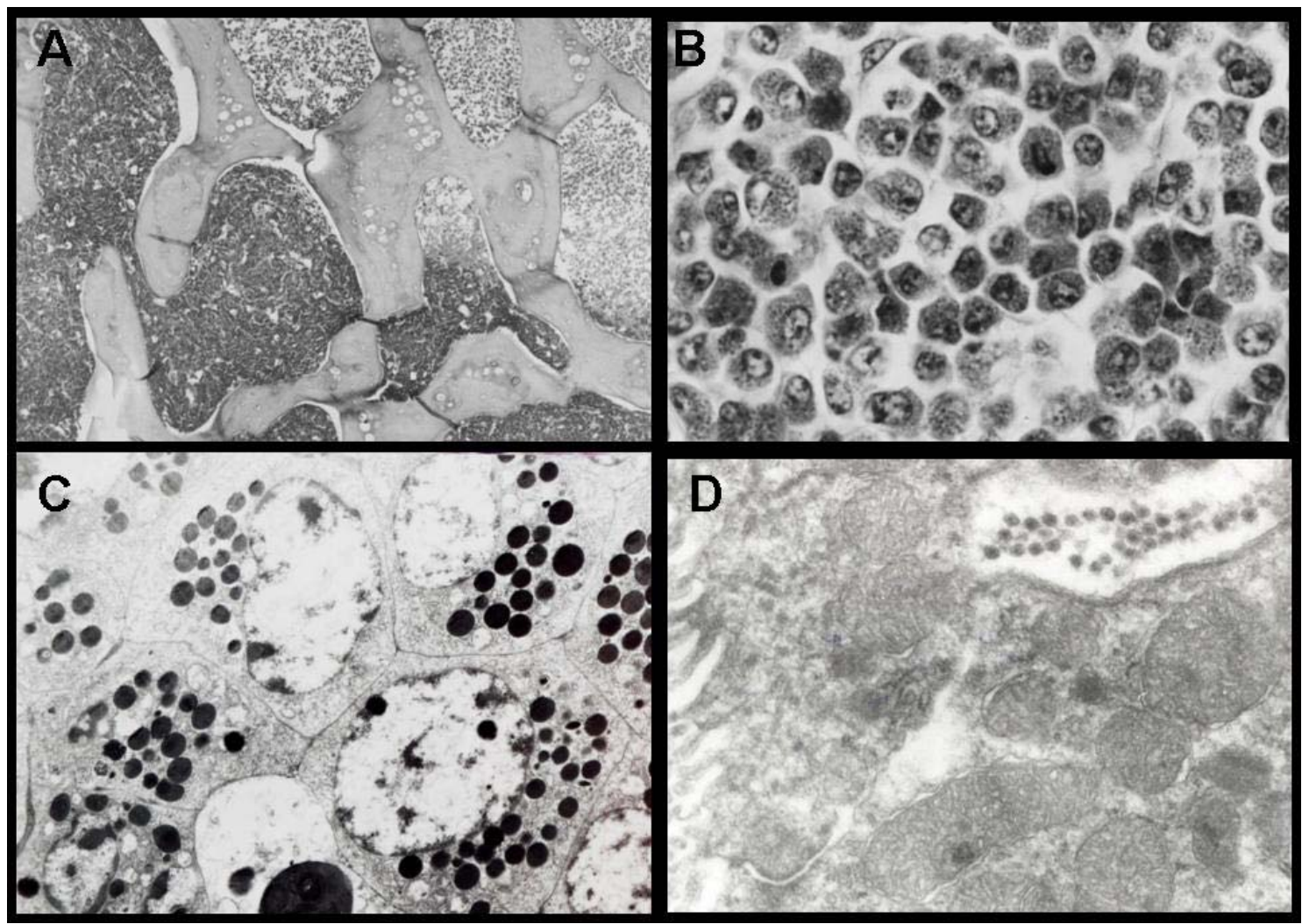

Figure 1. A- Proliferation of myelocytes in the bone marrow of the sternum. HE, 34X. B- Immature myelocytes with cytoplasmic eosinophilic granules. Some cells are in mitosis. HE, 360X. C- Electron micrograph of neoplastic myelocytes in the bone marrow. All granules are rounded and have similar size and electron density. Observe the lack of junctions among the cells. Uranyl acetate and lead citrate, 7.791X. D- Numerous viral particles in the intercellular space of the kidney. The viral particles have a centrally located electron-dense core separated from the envelope by an electron lucent space. Uranyl acetate and lead citrate, 76.867X. 


\section{DISCUSSION}

Microscopically, the morphology of the cellular type involved in myeloid leukosis was compatible with that of the myelocytes: cytoplasm filled with eosinophilic granules and voluminous nuclei of different shapes with evident nucleoli. Such features were also observed by Payne and Fadly (1997), but differ from those described by Jordan and Pattison (1996), who compares myeloid leukosis with myeloblastosis, a tumor containing large cells, slightly basophilic cytoplasm and voluminous nuclei. The microscopic study revealed cells with eosinophilic granules, typical of the myeloid lineage origin, that was previously reported (Payne et al., 1992). However, when working with HE stained tissues, it is difficult to classify the cellular type involved if solely based on light microscopy. The granules in these cells are morphologically very similar to those found in heterophils and eosinophils (Dhringa et al., 1969; Campbell, 1988) and ultrastructural analysis must be employed.

The cells identified under electron microscopy are irregular in shape and had a large oval nucleous with abundant cytoplasm containing numerous round electron-dense granules, as reported by Nakamura et al. (2000). The cytoplasm of the neoplastic cells was moderate in amount and contained abundant polyribosomes, with a considerable number of ribosomes, and moderate numbers of mitochondria. These findings confirm the description of Payne and Fadly (1997). These aspects are common to myelocytes, heterophils and eosinophils (Dhringa et al., 1969; Maxwell and Trejo, 1970; Hodges, 1974; Maxwell, 1978).

It is possible to differentiate heterophil and eosinophil myelocytes according to the structure of their granules. Heterophil myelocytes have a round shape and have two basic types of granules, a fusiform and elongated granule with globular content, and a round to oval granule with a fibrilar content (Maxwell and Trejo, 1970; Hodges, 1974). Eosinophil myelocytes are irregular in shape and have a homogenous population of granules, being all of them round and of fairly even size and density of content (Dhringa et al., 1969; Maxwell and Trejo, 1970; Hodges, 1974).
Analysing the cytoplasmic granules under the transmission eletron microscope, a homogenous population of granules was observed, being all of them round and with fairly even size and density of content, characteristics of eosinophil granules (Dhringa et al., 1969; Maxwell and Trejo, 1970; Hodges, 1974; Maxwell, 1978). In this study, the observed cytoplasmic granules were morphologically different from those of heterophils, which are fusiform and electrondense (Maxwell and Trejo, 1970; Hodges, 1974).

The spherical viral particles with electron-dense core, separated from the envelope by an electron lucent space observed in the intercellular space of the renal tubuli and in the cytoplasm of neoplastic cells in the bone marrow and ovary, were also reported by Nakamura et al. (2000). The shape of the central core and the budding morphology were extremely suggestive of avian leukosis virus (Payne, 1992).

Analysis of PCR assays with ALV-J specific primers (Smith et al., 1998) revealed positive reaction with DNA obtained from tumors, indicating that the viral particles which were observed in transmission electron microscopy were ALV-J.

This study provides new knowledge on the morphological characterization of myeloid leukosis in chickens. By the ultrastructural analysis, the studied neoplastic cells were morphologically identical to myelocytes and had eosinophilic granules that point to a myeloid lineage with differentiation to eosinophils.

\section{REFERENCES}

ANDREASEN, C.B.; LATIMER, K.S. Cytochemical staining characteristics of chicken heterophils and eosinophils. Vet. Clin. Pathol., v.19, p.51-54, 1990.

ASTER, J.; KUMAR, V. Leukocytes, lymph nodes, spleen and thymus. In: COTRAN, R.S.; KUMAR, V.; COLLINS, T. Robbins pathologic basis of disease. 6.ed. Philadelphia: W.B. Saunders, 1999. p.580-625.

CAMPBELL, T.W. Avian hematology and cytology. Ames: Iowa State University, 1988. p.3-17. 
DHRINGA, L.D.; PARRISH, W.B.; VENZKE, W.G. Electron microscopy of granular leukocytes of chicken (Gallus domesticus). Am. J. Vet. Res., v.30, p.637-643, 1969.

FADLY, A.M. Isolation and identification of avian leukosis viruses: a review. Avian Pathol., v.29, p.529-535, 2000.

HODGES, R.D. The histology of the fowl. London: Academic, 1974. p.150-242.

JORDAN, F.T.; PATTISON, M. Poultry diseases. 4.ed. Philadelphia: W. B. Saunders, 1996. p.123-133.

MAXWELL, M.H. The development of eosinophils in the bone marrow of the fowl and the duck. J. Anat., v.125, p.387-400, 1978.

MAXWELL, M.H.; TREJO, F. The ultrastructure of white blood cells and thrombocytes of the domestic fowl. Br. Vet. J., v.126, p.583-592, 1970.

NAKAMURA, K.; OGISO, M.; TSUKAMOTO, $\mathrm{K}$. et al. Lesions of bone and bone marrow in myeloid leukosis occurring naturally in adult broiler breeders. Avian Dis., v.44, p.215-221, 2000 .

PAYNE, L.N. Biology of avian retroviruses. In: LEVY, J.A. Retroviridae. New York: Plenum, 1992. p.299-404.

PAYNE, L.N. HPRS-103: a retrovirus strikes back. The emergence of subgroup $\mathrm{J}$ avian leukosis virus. Avian Pathol., v.27, p.S36-S45, 1998.

PAYNE, L.N.; BROWN, S.R.; BUMSTEAD, N. et al. A novel subgroup of exogenous avian leukosis virus in chickens. J. Gen. Virol., v.72, p.801-807, 1991.

PAYNE, L.N.; FADLY, A.M. Leukosis/sarcoma group. In: CALNEK, B.W. Diseases of poultry. 10.ed. Ames: Iowa State University, 1997. p.414-466.

PAYNE, L.N.; GILLESPIE, A.M.; HOWES, K. Recovery of acutely transforming viruses from myeloid leukosis induced by the HPRS-103 strain of avian leukosis virus. Avian Dis., v.37, p.438-450, 1993.

PAYNE, L.N.; GILLESPIE, A.M.; HOWES, K. Myeloid leukaemogenicity and transmission of the HPRS-103 strain of avian leukosis virus. Leukemia, v.6, p.1167-1176, 1992.

QIN, A.; LEE, L.F.; FADLY, A.M. et al. Development and characterization of monoclonal antibodies to subgroup $\mathrm{J}$ avian leukosis virus. Avian Dis., v.45, p.938-945, 2001.

SILVA, R.F.; FADLY, A.M.; HUNT, H.D. Hypervariability in the envelope genes of subgroup $\mathrm{J}$ avian leukosis virus obtained from different farms in the United States. Virology, v.272, p.106-111, 2000.

SMITH, L.M.; BROWN, S.R.; HOWES, K. et al. Development and application of polymerase chain reaction (PCR) tests for the detection of subgroup J avian leukosis virus. Virus Res., v.54, p.87-98, 1998.

STEDMAN, N.L.; BROWN, T.P.; BROWN, C.C. Localization of avian leukosis virus subgroup J naturally infected chickens by RNA in situ hybridization. Avian Dis., v.43, p.604610,2001 .

VENUGOPAL, K. Avian leukosis virus subgroup J: a rapidly evolving group of oncogenic retroviruses. Res. Vet. Sci., v.67, p.113-119, 1999.

WITTER, R.L; FADLY, A.M. Reduction of horizontal transmission of avian leukosis virus subgroup $\mathrm{J}$ in broiler breeder chickens hatched and reared in small groups. Avian Pathol., v.30, p.641-654, 2001. 